\title{
Tingkat Kecemasan Matematika Siswa SMA Negeri 2 Kerinci Kelas X MIA Sebelum Menghadapi Tes Matematika Berdasarkan Gender dan Hubungannya dengan Hasil Belajar
}

\author{
Irel Nofrialdi ${ }^{1}$, Maison $^{2}$, Muslim $^{3}$ \\ ${ }^{1,2,3}$ Program Magister Pendidikan Matematika Universitas Jambi, Jambi
}

Irel_nofrialdi90@yahoo.com

\begin{abstract}
This research aims to determine differences in student anxiety levels based on gender and the relationship between students' anxiety levels before facing a mathematical test with achievement and then dig deeper information about the causes of anxiety in students. This research uses mixed method method with sequential explanatory approach. The subjects of this study were students of class X MIA Kerinci Senior High School 2 totaling 100 students. The results of the research showed that students experiencing anxiety before taking a math test as the cause of anxiety is experience, intelligence, preperation and family. Differences in levels of anxiety based on gender indicate that there is no significant difference between the level of anxiety experienced by male and female students but male students are more anxious than female students the cause is that there have been similar thoughts and goals in terms of achievement so as to make male students neither men nor women experience significant differences in anxiety levels. There is a relationship between the level of anxiety with learning outcomes of 0.43 which is in the category enough and has a positive relationship, namely the higher the level of anxiety, the higher the student learning outcomes. Descriptions of quantitative data indicate that there is no certainty for someone who has an anxiety level will get a definite value.
\end{abstract}

Keywords: Mathematical Anxiety Level, Gender, Achievement

\begin{abstract}
Abstrak. Penelitian ini bertujuan untuk mengetahui perbedaan tingkat kecemasan siswa berdasarkan gender serta hubungan antara tingkat kecemasan siswa sebelum menghadapi tes matematika dengan hasil belajar kemudian menggali informasi yang lebih mendalam tentang penyebab kecemasan pada siswa. Penelitian ini menggunakan metode mixed method dengan pendekatan explanatoris sekuensial. Subjek penelitian ini adalah siswa kelas X MIA SMA Negeri 2 Kerinci yang berjumlah 100 siswa. Hasil penelitian menunjukkan bahwa siswa mengalami kecemasan sebelum mengikuti tes matematika adapun penyebab timbulnya kecemasan adalah kepribadian, kecerdasan, kesiapan, dan keluarga. Perbedaan tingkat kecemasan berdasarkan gender menunjukkan bahwa tidak ada perbedaan yang signifikan antara tingkat kecemasan yang dialami siswa laki-laki maupun perempuan namun siswa laki-laki lebih cemas dibandingkan dengan siswa perempuan penyebabnya adalah telah ada persamaan pemikiran dan tujuan dalam hal prestasi sehingga membuat siswa laki-laki maupun perempuan tidak mengalami perbedaan yang signifikan dalam tingkat kecemasan. Terdapat hubungan antaratingkat kecemasan dengan hasil belajar sebesar 0,43 yang berada pada kategori cukup dan mempunyai hubungan yang positif yaitu semakin tinggi tingkat kecemasan maka akan semakin tinggi hasil belajar siswa. Pendeskripsian terhadap data kuantitatif menunjukkan bahwa tidak ada kepastian bagi seseorang yang memiliki tingkat kecemasan akan mendapatkan nilai yang pasti.
\end{abstract}

Kata kunci: Tingkat Kecemasan Matematika, Gender, Hasil Belajar 


\section{PENDAHULUAN}

Dalam konteks pendidikan, guru mengajar agar peserta didik dapat belajar dan menguasai isi pelajaran hingga mencapai suatu tujuan yang ditentukan, yaitu: a) aspek kognitif, b) aspek afektif (sikap), c) aspek psikomotor (keterampilan).Menurut Hamalik (2007) belajar adalah suatu proses, bisa didapatkan dengan cara mengalami, berdasarkan pengalaman serta hasil dan buktinya dengan adanya perubahan tingkah laku dari tidak tahu menjadi tahu, dari tidak mengerti menjadi mengerti.

Kecemasan merupakan hal yang wajar yang pernah dialami oleh setiap individu dan tidak tertutup kemungkinan terjadinya kecemasan dalam belajar. Hasil penelitian yang dilakukan oleh Gierl dan Bisanz (1995) menunjukkan bahwa ada dua bentuk kecemasan matematika yaitu kecemasan pada saat tes dan kecemasan pemecahan masalah. Kecemasan matematika yang dialami oleh siswa seperti yang diungkapkan oleh Gierl dan Bisanz bisa menyebabkan rekasi yang positif dan reaksi yang negatif. Dalam penelitian yang dilakukan oleh Ashcraft (2002) mengungkapkan bahwa ketika seseorang memiliki kecemasan maka memunculkan kecemasan dalam tes dan memberikan hasil yang tidak maksimal. Kecemasan tidak selalu menimbulkan efek negatif namun bisa menjadi sebuah stimulus bagi siswa sebagaimana hasil penelitian Andrian (2017) mengungkapkan bahwa kecemasan dapat menimbulkan reaksi yang positif serta menjadi stimulus yang berguna dalam menyelesaikan masalah, tergantung dari seorang guru dalam mengarahkan agar kecemasan itu dapat menjadi positif.Kecemasan merupakan salah satu faktor yang menyebabkan rendahnya hasil belajar.Menurut Kaplan, Sadock dan Grebb (Fauziah \& Julianti, 2007:73) kecemasan adalah suatu respon terhadap situasi tertentu yang mengancam, dan merupakan hal yang normal menyertai perkembangan, perubahan, pengalaman baru atau yang belum pernah dilakukan, serta dalam menemukan identitas diri. Kecemasan yang berlebihan akan menimbulkan gangguan dan menjadi penghambat fungsi seseorang dalam kehidupannya.

Menurut Suliswati (2012) kecemasan akan menimbulkan dua bentuk reaksi yaitu reaksi konstruktif dan reaksi destruktif. Reaksi kontruktif adalah bentuk reaksi yang dapat memotivasi indivitu untuk belajar dan membuat perubahan terhadap perasaan tidak nyaman sedangkan reaksi destruktif adalah individu melakukan hal-hal yang maladaktif dan disfungsional. Hasil penelitian Andrian (2017) mengungkapkan bahwa kecemasan dapat menimbulkan reaksi yang positif serta menjadi stimulus yang berguna dalam menyelesaikan masalah, tergantung dari seorang guru dalam mengarahkan agar kecemasan itu dapat menjadi positif. Hasil penelitian Auliya (2016) menunjukkan bahwa kecemasan matematika berpengaruh signifikan terhadap kemampuan pemahaman matematis peserta didik. Hasil penelitian Gierl dan Bisanz (1995) mengungkapkan bahwa tidak ada perbedaan kecemasan matematika antara laki-laki dan perempuan pada siswa kelas 3 dan 6.

Kecemasan berdasarkan gender merupakan hal yang menarik untuk ditinjau, kecemasan matematika terjadi pada saat siswa akan mengikuti tes hasil belajar dan ada beberapa faktor yang mempengaruhi hasil belajar yang juga dapat menyebabkan siswa mengalami kecemasan karena faktor-faktor tersebut. Faktor-faktor yang mempengaruhi hasil belajar yang juga dapat menyebabkan siswa mengalami kecemasan seperti faktor psikologis, sekolah, dan keluarga (Slameto, 2015). Unger (Umar, 1999:42) menyatakan bahwa ada beberapa keunggulan yang dimiliki oleh laki-laki dibandingkan dengan perempuan, diantaranya: (1) laki-laki lebih suka pengetahuan eksakta dan hal-hal abstrak daripada perempuan, (2) laki-laki lebih berfikir logis daripada perempuan, (3) laki-laki lebih mampu mengatasi persoalan yang dihadapi daripada perempuan, (4) laki-laki lebih agresif daripada perempuan, (5) laki-laki lebih percaya diri daripada perempuan, (6) laki-laki lebih objektif daripada perempuan, (7) laki-laki kurang emosional daripada perempuan, (8) laki-laki lebih independen daripada perempuan, dan (9) laki-laki lebih mudah membedakan rasa dan rasio daripada perempuan. Menurut Susento (2006) Perbedaan gender tidak hanya berakibat pada kemampuan dalam matematika, tetapi juga cara dalam memperoleh pengetahuan matematika. Sedangkan menurut Santrock (2003) rata-rata performa matematika laki-laki lebih tinggi dibandingkan dengan perempuan, namun tidak semua laki-laki memiliki performa yang lebih baik dibandingkan dengan perempuan. 
Berdasarkan uraian diatas dan untuk mengungkapkan lebih jauh dan menggali lebih dalam tentang tingkat kecemasan matematika siswa SMA Negeri 2 Kerinci kelas X MIA terhadap hasil belajar, diperlukan suatu penelitian mengenai "tingkat kecemasan matematika siswa SMA Negeri 2 Kerinci kelas X MIA sebelum menghadapi tes matematika berdasarkan gender dan hubungannya dengan hasil belajar".

\section{METODE}

Penelitian ini menggunakan metode mixed method dengan desain sequensial explanatory. Menurut Creswell (2010) sequensial explanatory adalah penelitian yang dilakukan secara bertahap dimulai dari penelitian kuantitatif dan dilanjutkan dengan penelitian kualitatif. Penelitian kuantitatif menggunakan jenis penelitian korelasional, sedangkan penelitian kualitatif menggunakan jenis penelitian deskriptif. Teknik pengumpulan data kuantitatif dengan menggunakan angket kecemasan, tes hasil belajar dan observasi sedangkan untuk pengumpulan data kualitatif dengan wawancara.

\section{Populasi dan Sampel}

Penelitian ini dilakukan di SMA Negeri 2 Kerinci pada siswa kelas X MIA dan dilaksanakan pada semester genap tahun pelajaran 2017/2018. Populasi dalam penelitian ini berjumlah 135 siswa yang terbagi dalam 6 kelas dimulai dari X MIA 1 sampai X MIA 6. Banyaknya sampel yang akan digunakan pada penelitian ini ditentukan dengan menggunakan rumus slovin, yaitu:

$$
S=\frac{N}{N(d)^{2}+1}=\frac{1}{1 \quad(0,0)^{2}+1}=\frac{1}{1,3}=100 \text { siswa }
$$

Dengan menggunakan rumus slovin maka diperoleh sampel yang akan digunakan dalam penelitian ini sebanyak 100 orang.

Untuk menentukan sampel dengan menggunakan teknik random sampling yaitu sampel diambil secara acak dari populasi. Populasi terlebih dahulu diberi nomor urut dari 1 sampai 135 yang dimulai dari siswa kelas X MIA 1 sampai siswa X MIA 6 sesuai dengan absen kelas kemudian dengan pertimbangan agar populasi memiliki peluang yang sama untuk menjadi sampel maka dibantu dengan menggunakan excel.

\section{HASIL PENELITIAN}

Tingkat kecemasan siswa SMA Negeri 2 Kerinci kelas X MIA yang diperoleh sebelum tes hasil belajar dilakukan. Hasilnya seperti pada Tabel 1.

Tabel 1 Klasifikasi Tingkat Kecemasan Siswa

\begin{tabular}{l|l|l|l}
\hline Rentang skor & Tingkat kecemasan & Jumlah siswa & $\%$ \\
\hline $\mathrm{X}<14$ & Tidak ada kecemasan & 25 & $25 \%$ \\
\hline $14 \leq \mathrm{X}<21$ & Ringan & 34 & $34 \%$ \\
\hline $21 \leq \mathrm{X}<28$ & Sedang & 20 & $20 \%$ \\
\hline $28 \leq \mathrm{X}<42$ & Berat & 17 & $17 \%$ \\
\hline $42 \leq \mathrm{X} \leq 56$ & Panik & 4 & $4 \%$ \\
\hline
\end{tabular}

Sumber: Hawari, 2011

Berdasarkan Tabel 1 tingkat kecemasan siswa SMA Negeri 2 Kerinci Kelas X MIA yang diperoleh sebelum tes hasil belajar dilakukan, dari 100 orang sampel didapatkan sebanyak 25 orang siswa (25\% dari sampel) tidak mengalami tingkat kecemasan, 34 orang siswa (34\% dari sampel) mengalami tingkat kecemasan ringan, 20 orang siswa (20\% dari sampel) mengalami tingkat 
kecemasan sedang, 17 orang siswa (17\% dari sampel) mengalami tingkat kecemasan berat, dan 4 orang siswa (4\% dari sampel) mengalami tingkat kecemasan panik.

\section{Uji Prasyarat}

Sebelum melakukan uji hipotesis perlu dilakukan uji prasyarat yang meliputi uji normalitas, uji homogenitas, dan uji lineritas untuk mengetahui apakah uji hipotesis yang dilakukan adalah parametrik atau non parametrik.

\section{Uji Normalitas}

Tabel 2 Uji Normalitas Data Tingkat Kecemasan Siswa dan Hasil Belajar

\begin{tabular}{l|l|l|l}
\hline Variabel & Statistic & Df & Sig \\
\hline Tingkat kecemasan & 0,076 & 100 & 0,173 \\
\hline Hasil belajar & 0,081 & 100 & 0,107 \\
\hline
\end{tabular}

Sumber: Hasil Pengolahan Data

Dari hasil uji normalitas Kolmogorof-Smirnov diperoleh nilai signifikansi untuk tingkat kecemasan adalah 0,173 dan nilai signifikansi untuk hasil belajar adalah 0,107 yang berarti lebih besar dari nilai probabilitasnya yaitu 0,05 . Dari hasil uji normalitas dapat disimpulkan bahwa tingkat kecemasan dan hasil belajar berdistribusi normal.

\section{Uji Homogenitas}

\begin{tabular}{llll}
\multicolumn{3}{l}{ Tabel 3 Uji Homogenitas Hasil Belajar Siswa Berdasarkan Tingkat Kecemasan } \\
\hline Levene statistic & $\mathrm{df} 1$ & $\mathrm{df} 2$ & Sig \\
\hline 1,098 & 24 & 63 & 0,372 \\
\hline
\end{tabular}

Sumber: Hasil Pengolahan Data

Berdasarkan Tabel 3 diperoleh nilai signifikansi sebesar 0,372 yang berarti lebih besar dari nilai probabilitas yaitu 0,05 maka dapat disimpulkan bahwa data tersebut bersifat homogen.

\section{Uji Lineritas}

\begin{tabular}{l|l|l|l} 
Tabel 4 Uji Lineritas Hasil Belajar Dengan Tingkat Kecemasan \\
\hline Variabel & \multicolumn{2}{l}{ Deviation from linearity } \\
\cline { 2 - 4 } & $\mathrm{df}$ & $\mathrm{F}$ & Sig \\
\hline Hasil belajar*tingkat kecemasan & 35 & 2,011 & 0,008 \\
\hline
\end{tabular}

Sumber: Hasil Pengolahan Data

Berdasarkan Tabel 4 menunjukkan bahwa nilai signifikansisebesar 0,008 yang berarti lebih kecil dari nilai probabilitas sebesar 0,05 maka dapat disimpulkan bahwa hubungan variabel tingkat kecemasan dengan hasil belajar bersifat linear.

\section{Uji Hipotesis}

Hasil uji prasyarat yang telah dilakukan diperoleh bahwa data tersebut berdistribusi normal, bersifat homogen dan bersifat linear maka dapat dilanjutkan dengan melakukan uji hipotesis yang bersifat parametrik berupa uji beda dan analisis korelasi serta analisis regresi. 


\section{Uji Beda}

Uji beda bertujuan untuk mengetahui perbedaan tingkat kecemasan antara laki-laki dan perempuan. Uji beda dilakukan dengan menggunakan uji independent sample T-test.

Tabel 5 Uji Beda Tingkat Kecemasan antara Laki-Laki dan Perempuan

\begin{tabular}{c|l|l|l|l|c}
\hline Variabel & Jenis kelamin & $\mathrm{N}$ & Mean & $\mathrm{T}$ & Sig. (2-tailed) \\
\hline \multirow{2}{*}{ Tingkat kecemasan } & Laki-laki & 45 & 20,84 & \multirow{2}{*}{1,325} & \\
\cline { 2 - 5 } & Perempuan & 55 & 18,20 & \multirow{2}{*}{0,188} \\
\hline
\end{tabular}

Sumber: Hasil Pengolahan Data

Berdasarkan Tabel 5 diperoleh nilai untuk uji beda tingkat kecemasan antara laki-laki dan perempuan sebesar 0,188, sedangkan nilai probabilitas adalah 0,05 atau 0,188 >0,05 maka dapat disimpulkan bahwa tidak ada perbedaan tingkat kecemasan antara siswa laki-laki dengan siswa perempuan. Namun berdasarkan nilai mean dapat diperoleh bahwa siswa laki-laki lebih cemas dibandingkan dengan perempuan.

\section{Analisis Korelasi}

Analisis korelasi bertujuan untuk mengetahui hubungan antara tingkat kecemasan dengan hasil belajar. Koefisien korelasi berkisar antara -1 sampai 1 dan termasuk nol (0) di dalamnya. Semakin mendekati angkat 1 maka hubungan tersebut semakin kuat. Apabila koefisien korelasi bernilai nol (0) maka tidak ada hubungan antara variabel tersebut.

\begin{tabular}{ccccc} 
& \multicolumn{2}{c}{ Tabel 6 Analisis Korelasi } & & \\
\hline Variabel & & Hasil belajar & $\mathrm{r}^{2}$ & $\mathrm{t}$ \\
\hline Tingkat kecemasan & Pearson correlation & 0,43 & 0,186 & 4,740 \\
\hline
\end{tabular}

Sumber: Hasil Pengolahan Data

Berdasarkan Tabel 6 hasil analisis korelasi antara tingkat kecemasan dengan rata-rata hasil belajar menghasilkan koefisien korelasi sebesar 0,43 yang berada pada interval 0,40-0,60 dengan tingkat hubungan cukup. Uji koefisien korelasi dilakukan dengan membandingkan nilai $\mathrm{t}_{\text {hitung }}$ dengan nilai $t_{\text {tabel }}$, nilai $t_{\text {hitung }}$ diperoleh sebesar 4,740 sedangkan nilai $t_{\text {tabel }}$ untuk tingkat kepercayaan 95\% adalah sebesar 2,276 yang berarti bahwa nilai $t_{\text {hitung }}>$ nilai $t_{\text {tabel }}$ atau 4,740>2,276 maka dapat disimpulkan untuk hipotesis kedua $\mathrm{H}_{0}$ ditolak yang artinya ada hubungan antara tingkat kecemasan dengan hasil belajar. Hubungan antara tingkat kecemasan dengan hasil belajar merupakan hubungan yang positif yang berarti bahwa semakin tinggi tingkat kecemasan matematika siswa semakin tinggi hasil belajarnya. Koefisien determinasi untuk hubungan tingkat kecemasan dan hasil belajar sebesar 0,1865 yang berarti tingkat kecemasan mempengaruhi hasil belajar sebesar $18,6 \%$ dan sebanyak $81,4 \%$ dipengaruhi oleh faktor lain. Sebaran data tingkat kecemasan dengan hasil belajar dapat dilihat pada Gambar 1 .

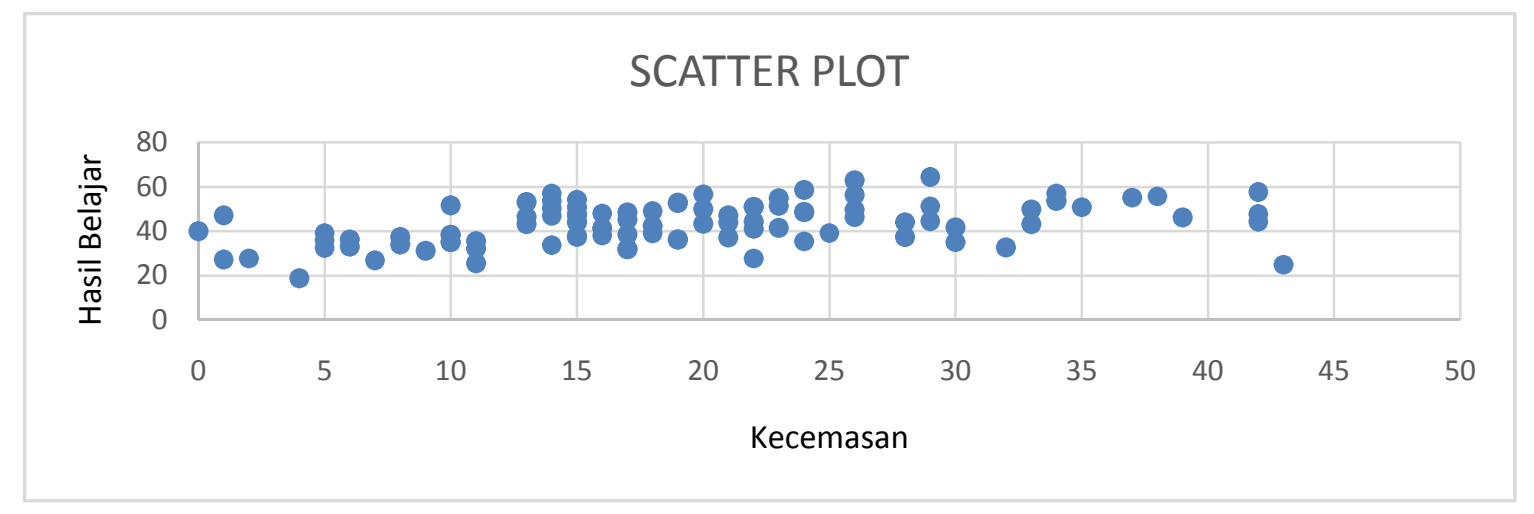

Gambar 1 Sebaran Data 


\section{Data Observasi}

Berdasarkan data observasi siswa SMA Negeri 2 Kerinci kelas X MIA baik laki-laki maupun perempuan mengalami beberapa aspek kecemasan, diantaranya pada aspek psikologis, somatik, kognitif dan motorik. Diantara beberapa aspek tersebut, yang paling menonjol adalah pada aspek psikologis karena hampir sebagaian besar siswa terlihat mengalami aspek tersebut seperti tegang dan gelisah ketika mengikuti tes matematika. Pada aspek kognitif yang sering dialami oleh siswa adalah sering lupa dengan pelajaran yang telah diajarkan oleh guru sebelumnya, Pada aspek lainnya seperti aspek somatik dan motorik juga terjadi pada siswa namun tidak terlalu menonjol, seperti siswa yang terbata-bata ketika ditanya serta siswa yang kelihatan pusing ketika menjawab soal tes hasil belajar.

\section{Data Kualitatif}

\section{Data Wawancara}

Berdasarkan data wawancara yang telah dikumpulkan dari sumber yang dapat dipercaya dan melalui proses pengumpulan, merangkum, menyajikan data serta penarikan kesimpulan, maka data wawancara telah ditabulasikan berdasarkan katergori-kategori yaitu:

\begin{tabular}{|c|c|c|}
\hline No & Kategori & Data kualitatif \\
\hline 1 & Kepribadian/Pengalaman & $\begin{array}{l}\text { Siswa mengalami kecemasan karena pengalamannya pada masa lalu yang } \\
\text { berhubungan dengan matematika. ketika mengikuti pelajaran matematika dari } \\
\text { SD sampai SMA cukup memberikan pengaruh, munculnya perasaan dari } \\
\text { siswa yang merasa tidak mampu dalam menyelesaikan soal-soal tes yang } \\
\text { akan diberikan serta ketakutan jika mendapatkan nilai yang jelek karena dapat } \\
\text { menimbulkan malu dan membuat harga diri menjadi turun. Pengawasan dari } \\
\text { orang tua membuat mereka lebih giat. }\end{array}$ \\
\hline 2 & Kecerdasan/Intelektual & $\begin{array}{l}\text { Kecerdasan yang dimiliki oleh setiap siswa tidak sama, sehingga } \\
\text { menyebabkan adanya ketimpangan dari segi pemahaman siswa dalam } \\
\text { memahami materi yang diberikan oleh guru. Hal ini menyebabkan siswa } \\
\text { mengalami kecemasan pada saat akan mengikuti tes matematika karena } \\
\text { munculnya perasaan ketidakmampuan siswa dalam menjawab soal tes yang } \\
\text { akan diterima. }\end{array}$ \\
\hline 3 & Kesiapan & $\begin{array}{l}\text { Siswa mempersiapkan diri untuk mengikuti tes matematika dengan } \\
\text { mengulangi pelajaran, mencoba menjawab soal-soal yang pernah dipelajari, } \\
\text { menanyakan kepada guru tentang materi yang belum dipahami namun tidak } \\
\text { membuat mereka menjadi tidak cemas ketika akan mengikuti tes matematika. }\end{array}$ \\
\hline 4 & Kelelahan & $\begin{array}{l}\text { Siswa SMA Negeri } 2 \text { Kerinci kelas X MIA selalu menjaga kesehatan agar } \\
\text { terhindar dari kelelahan, rutinitas yang dilakukan diluar sekolah hanya } \\
\text { rutinitas biasa seperti membatu orang tua, bermain, serta mengulangi } \\
\text { pelajaran. }\end{array}$ \\
\hline 5 & Keluarga & $\begin{array}{l}\text { Orang tua memberikan perhatian yang lebih kepada anak-anak mereka ketika } \\
\text { pulang dari sekolah, hal ini dilakukan ketika mereka sekolah dari SD sampai } \\
\text { SMA, selalu memotivasi serta mamantau nilai yang didapatkan oleh siswa } \\
\text { ketika mereka mengikuti pelajaran disekolah. Hal ini menyebabkan siswa } \\
\text { mengalami kecemasan karena secara tidak langsung dengan pengawasan } \\
\text { yang dilakukan oleh orang tua membuat siswa tersebut berupaya untuk } \\
\text { memberikan yang terbaik. }\end{array}$ \\
\hline 6 & Sekolah & $\begin{array}{l}\text { Siswa merasa senang dengan cara guru dalam mengajar, tidak terlalu serius } \\
\text { namun tujuan tercapai yaitu siswa menjadi mengerti. Membuat pelajaran } \\
\text { menjadi tidak membosankan serta mudah untuk dipahami, berusaha untuk } \\
\text { tidak menciptakan suasana tegang di dalam kelas terutama ketika belajar } \\
\text { matematika serta sekolah berusaha untuk memberikan segala upaya yang } \\
\text { maksimal dalam melakukan pembelajaran, dengan menyiapkan sarana dan } \\
\text { prasarana yang memadai. }\end{array}$ \\
\hline
\end{tabular}

Tingkat Kecemasan Matematika Siswa Sebelum Mengikuti Tes Matematika

Berdasarkan data wawancara yang telah dikumpulkan diperoleh data kualitatif tentang tingkat kecemasan matematika siswa sebelum mengikuti tes matematika. Data kualitatif tersebut disajikan dalam Tabel 8. 


\begin{tabular}{l|l|l}
\multicolumn{2}{c}{ Tabel 8 Tingkat Kecemasan Matematika } \\
\hline No & Kategori & \multicolumn{1}{c}{ Data kualitatif } \\
\hline 1 & $\begin{array}{l}\text { Kepribadian/p } \\
\text { engalaman }\end{array}$ & $\begin{array}{l}\text { Pengalaman dalam mengikuti pelajaran matematika memberikan pengaruh terhadap munculnya } \\
\text { kecemasan ketika akan mengikuti tes matematika }\end{array}$ \\
\hline 2 & Kecerdasan & $\begin{array}{l}\text { Kecerdasan menyebabkan seseorang mengalami kecemasan karena adanya perbedaan dalam } \\
\text { memahami materi. }\end{array}$ \\
\hline 3 & Kesiapan & $\begin{array}{l}\text { Persiapan yang dilakukan oleh siswa tidak membuat siswa tersebut menjadi tidak cemas dalam } \\
\text { menghadapi tes matematika }\end{array}$ \\
\hline 4 & Keluarga & $\begin{array}{l}\text { Tuntutan dari keluarga yang menginginkan siswa tersebut mendapatkan nilai yang baik juga } \\
\text { menyebabkan timbulnya kecemasan bagi siswa. }\end{array}$ \\
\hline
\end{tabular}

Berdasarkan data kualitatif pada Tabel 8 yang telah dikumpulkan pada saat observasi dan wawancara diperoleh bahwa siswa SMA Negeri 2 Kerinci mengalami kecemasan matematika ketika akan mengikuti tes matematika.

\section{Perbedaan Tingkat Kecemasan Matematika Siswa Berdasarkan Gender}

Berdasarkan data wawancara yang telah dikumpulkan diperoleh data kualitatif tentang perbedaan tingkat kecemasan matematika siswa berdasarkan gender. Dari data tersebut dapat disimpulkan bahwa baik siswa laki-laki maupun perempuan mengalami tingkat kecemasan pada saat akan menghadapi tes hasil belajar yang dimulai dari kategori tidak ada kecemasan sampai ke tingkat panik dan tersebar hampir secara merata.

\section{Hubungan Tingkat Kecemasan Matematika Siswa dengan Hasil Belajar}

Data kualitatif yang ketiga adalah untuk membuktikan, memperdalam, memperkuat, dan memperluas data tentang hubungan tingkat kecemasan matematika siswa dengan hasil belajar. Hasil penelitian kuantitatif menunjukkan bahwa nilai korelasi antara tingkat kecemasan matematika dengan hasil belajar sebesar 0,43, nilai ini termasuk kategori cukup. Yang berarti bahwa hubungan antara tingkat kecemasan matematika dengan hasil belajar cukup dan mempunyai hubungan yang positif.

Berdasarkan data wawancara diperoleh data kualitatif tentang hubungan tingkat kecemasan matematika siswa dengan hasil belajar:

1) Kecemasan yang dialami oleh siswa dapat memberikan reaksi yang positif dan reaksi yang negatif tergantung bagaimana faktor eksternal mempengaruhinya.

2) Faktor eksternal yang dapat menimbulkan reaksi yang positif berupa sekolah yaitu guru serta teman sekolah yang terbagi dalam beberapa hal metode mengajar, hubungan guru dengan siswa, hubungan siswa dengan siswa.

\section{Deskripsi Tingkat Kecemasan yang Sama terhadap Hasil Belajar}

Data kualitatif yang keempat peneliti mendeskripsikan data kuantitatif, berdasarkan data kuantitatif pada (lampiran 1), telah diklasifikasikan siswa berdasarkan tingkat kecemasan terhadap hasil belajar. Dari data tersebut dapat ditarik kesimpulan bahwa seseorang yang berada pada tingkat kecemasan yang sama bisa menghasilkan hasil belajar yang berbeda.

\section{PEMBAHASAN}

Data kualitatif menjelaskan bahwa siswa mengalami kecemasan ketika akan mengikuti tes matematika, data kualitatif tersebut memperkuat, memperdalam, dan memperluas data kuantitatif yang telah mengklasifikasikan tingkatan kecemasan matematika yang dialami oleh siswa SMA Negeri 2 Kerinci kelas X MIA yang dimulai dari tidak ada kecemasan sampai tingkat kecemasan panik. Adapun kecemasan yang dialami oleh siswa secara kualitatif karena adanya perasaan ketidakmampuan dalam menjawab soal-soal tes yang akan diberikan dan ketakutan jika mendapat nilai yang tidak memuaskan sebab dapat menyebabkan siswa tersebut menjadi malu serta turunnya 
harga diri. Hal inilah yang membuat siswa menjadi cemas dan munculnya perasaan tersebut merupakan sebuah respon yang disebabkan oleh kepribadian, kecerdasan, kesiapan serta keluarga. hal ini sejalan dengan pendapat Kaplan, Sadock dan Grebb (Fauziah dan Julianti, 2007:73) kecemasan adalah suatu respon terhadap situasi tertentu yang mengancam, dan merupakan hal yang normal menyertai perkembangan, perubahan, pengalaman baru atau yang belum pernah dilakukan, serta dalam menemukan identitas diri. Suliswati (2012) juga mengungkapkan bahwa salah satu faktor yang mencetuskan timbulnya kecemasan adalah adanya ancaman terhadap harga diri. Serta teori psikoanalitik tentang kecemasan yang menjelaskan bahwa kecemasan bisa timbul karena reaksi psikologi individu terhadap ketidakmampuannya.

Data kuantitatif menjelaskan bahwa tidak ada perbedaan yang signifikan antara tingkat kecemasan siswa laki-laki dan perempuankemudian data kualitatif yang memperdalam, memperkuat data kuantitatif tersebut adalah tidak adanya perbedaan yang signifikan antara tingkat kecemasan siswa laki-laki dan siswa perempuan disebabkan oleh pandangan dan tujuan yang telah sama dari siswa laki-laki dan perempuan yang kemudian menyebabkan tingkat kecemasan yang dialamipun tidak memiliki perbedaan yang signifikan. Hal ini sejalan dengan hasil penelitian Gierl dan Bizanz (1995) yang tidak menemukan bukti bahwa ada perbedaan kecemasan matematika antara laki-laki dengan perempuan. Santrock (2003) mengungkapkan bahwa rata-rata performa matematika laki-laki lebih tinggi dibandingkan dengan perempuan, namun tidak semua laki-laki memiliki performa yang lebih baik dibandingkan dengan perempuan.

Data kuantitatif menjelaskan bahwa ada hubungan antara tingkat kecemasan matematika terhadap hasil belajar yang nilainya $=0,43$ (berada pada kategori cukup dan mempunyai hubungan yang positif). Data kualitatif yang memperdalam, memperkuat dan memperluasdata kuantitatif tersebut adalah kecemasan yang dialami oleh siswa bisa menimbulkan reaksi yang positif dan negatif tergantung bagaimana faktor-faktor eksternal mempengaruhinya. Faktor-faktor eksternal yang dapat membuat kecemasan menjadi positif serta penyebab timbulnya kecemasan yang dirasakan siswa SMA Negeri 2 Kerinci kelas X MIA dapat dilihat pada Tabel 9.

Tabel 9 Faktor-Faktor Eksternal serta Penyebab Timbulnya Kecemasan

\begin{tabular}{l|l|l|l}
\hline No & $\begin{array}{l}\text { Faktor timbulnya } \\
\text { kecemasan }\end{array}$ & Penyebabnya & Faktor eksternal agar menjadi positif \\
\hline 1 & Kepribadian & Pengalaman individu dimasa lalu & $\begin{array}{l}\text { Meyakinkan siswa bahwa kesalahan yang } \\
\text { dilakukan dimasa lalu dapat diperbaiki pada saat } \\
\text { ini }\end{array}$ \\
\hline 2 & Kecerdasan & Tidak yakin akan kemampuannya & Meyakinkan siswa tentang kemampuannya \\
\hline 3 & Kesiapan & $\begin{array}{l}\text { Tidak yakin dengan persiapan yang } \\
\text { dilakukan/ takut tidak sesuai dengan apa } \\
\text { yang dipersiapkan }\end{array}$ & $\begin{array}{l}\text { Meminimalisir kekhawatiran siswa tentang tes } \\
\text { yang akan dihadapinya }\end{array}$ \\
\hline 4 & Keluarga & $\begin{array}{l}\text { Tuntutan dari keluarga yang tinggi } \\
\text { andongang siswa untuk lebih baik karena adanya }\end{array}$ \\
\hline
\end{tabular}

Sebagian siswa merasa termotivasi dengan adanya kecemasan karena faktor-faktor yang mempengaruhi kecemasan itu bisa memberikan efek positif dan efek negatif bagi siswa dalam mengikuti tes hasil belajar. Namun agar kecemasan itu dapat menjadi hal yang positif diperlukan bantuan dari eksternal seperti sekolah yang dalam hal ini adalah guru dalam mengarahkan, serta teman yang dapat saling mendukung. Apabila tidak dibantu dari eksternal maka kemungkinan kecemasan itu menjadi sebuah hal yang positif akan semakin kecil dan cenderung mengarah kepada hal yang negatif. Gierl dan Bisanz (1995) mengungkapkan bahwa kecemasan matematika terjadi pada saat siswa akan mengikuti tes matematika. Gierl dan Bisanz juga mengungkapkan bahwa walaupun siswa lebih merasa cemas terhadap tes akademis namun siswa juga merasa cemas terhadap tes matematika.Sejalan dengan hasil penelitian Andrian (2017) bahwa kecemasan dapat menjadi sebuah stimulus dalam menyelesaikan masalah tergantung dari seorang guru dalam mengarahkan.Hal yang sama juga disampaikan oleh Suliswati (2012) bahwa semua tingkatan kecemasan dapat menimbulkan reaksi konstruktif dan reaksi destruktif.

Berdasarkan data kuantitatif yang telah diklasifikasikan sebagaimana (lampiran 1), dapat disimpulkan bahwa siswa yang memiliki tingkat kecemasan yang sama tidak akan mendapatkan 
hasil yang sama. Hal ini sejalan dengan apa yang disampaikan oleh Suliswati (2012) bahwa semua tingkatan kecemasan dapat menimbulkan reaksi konstruktif dan reaksi destruktif tergantung bagaimana faktor-faktor lain mempengaruhinya. Kecemasan merupakan salah satu faktor yang mempengaruhi hasil belajar secara psikologi dan masih banyak lagi faktor-faktor lain yang bisa mempengaruhi hasi belajar (Slameto, 2015).

\section{KESIMPULAN}

Berdasarkan pembahasan diatas, maka dapat disimpulkan bahwa:

1. Data kuantitatif dan kualitatif menjelaskan bahwa siswa SMA Negeri 2 Kerinci kelas X MIA mengalami kecemasan ketika akan menghadapi tes matematika, adapun faktor-faktor yang menyebabkan siswa mengalami kecemasan adalah kepribadian/pengalaman siswa dimasa lalu, siswa yang tidak yakin dengan kecerdasan/intelektual yang dimilikinya, kesiapan yang berhubungan dengan kecerdasan membuat siswa menjadi tidak yakin dengan persiapan yang telah dilakukannya, serta keluarga yang mempunyai tuntutan yang tinggi terhadap nilai yang harus didapatkan oleh siswa tersebut.

2. Data kuantitatif dan kualitatif menjelaskan bahwa tidak ada perbedaan yang signifikan antara tingkat kecemasan siswa laki-laki dengan siswa perempuan. Namun siswa laki-laki lebih cemas dibandingkan dengan siswa perempuan. Hal ini disebabkan karena pemikiran sama terhadap tes yang akan dihadapi untuk meraih prestasi disekolah. Data dokumentasi menunjukkan bahwa bukan hanya siswa perempuan saja yang mendominasi dalam perolehan peringkat disekolah namun tidak sedikit juga siswa laki-laki yang memperoleh peringkat disekolah. Karena pemahaman dan tujuan yang sama dalam hal prestasi menyebabkan tidak adanya perbedaan yang signifikan antara siswa laki-laki dan perempuan dalam hal tingkat kecemasan.

3. Data kuantitatif menjelaskan bahwa hubungan antara tingkat kecemasan matematika dengan hasil belajar berada pada kategori cukup dan mempunyai hubungan yang positif. Data kualitatif menjelaskan bahwa siswa mengalami kecemasan ketika akan mengikuti tes hasil belajar. Kecemasan yang dialami disebabkan oleh faktor kepribadian, kecerdasan, kesiapan, dan keluarga. Faktor-faktor kecemasan bisa memberikan efek positif dan efek negatif bagi siswa dalam mengikuti tes hasil belajar. Agar kecemasan itu dapat menjadi hal yang positif diperlukan bantuan dari eksternal seperti sekolah yang dalam hal ini adalah guru yaitu metode mengajar, hubungan guru dengan siswa serta teman yang dapat saling mendukung. Apabila tidak dibantu oleh faktor eksternal maka kemungkinan kecemasan itu menjadi sebuah respon yang positif akan semakin kecil dan cenderung mengarah kepada respon yang negatif.

4. Data kualitatif yang didapatkan dari pendeskripsian data kuantitatif dapat disimpulkan bahwa tidak ada kepastian bagi seseorang yang mengalami salah satu tingkatan kecemasan yang sama maka hasil belajarnya dapat diprediksi sama, karena kecemasan yang dialami oleh siswa hanya berpengaruh sebesar 18,6\% dan sisanya dipengaruhi oleh faktor-faktor lain.

\section{DAFTAR PUSTAKA}

Adrian, D. 2017. Mengelola Kecemasan Siswa Dalam Pembelajaran Matematika. Jurnal Nasional Matematika. 440 - 449.

Ashcraft, M, H. 2002. Math Anxiety: Personal, Educational and Cognitive Consequences. Current Directions in Psychological Science. 11(5).

Auliya, R, N. 2016. Kecemasan Matematika dan Pemahaman Matematis. Jurnal Formatif. 6(1), 12 -22 . 
Creswell, J.W. 2010. Research Desaign: Pendekatan Kualitatif, Kuantitatif dan Mixed. Yogyakarta: PT Pustaka Pelajar

Fauziah, F \& Julianti W. 2007. Psikologi Abnormal Klinis Dewasa. Jakarta. Universitas Indonesia (UI-Press).

Gierl J. M and Bisanz, J. 1995. Anxieties and Attitudes Related to Mathematics in Grade 3 and 6. The Journal of Experimental Education. Universitas Alberta. 63(2), 139-158.

Hamalik, O. 2007. Proses Belajar Mengajar. Jakarta. PT Bumi Aksara.

Santrock, J,W.2003. Perkembangan Remaja. Jakarta: Erlangga

Slameto. 2015. Belajar dan Faktor-Faktor yang Mempengaruhinya. Jakarta: Rineka Cipta.

Stuart Gail W. 2013. Buku saku keperawatan jiwa edisi 5. Jakarta. EGC.

Susento. 2006. Mekanisme Interaksi Antara Pengalaman Kultural-Matematis, Proses Kognitif, Dan Topangan Dalam Reivensi Terbimbing[Disertasi]. Surabaya: Unesa

Suliswati. 2012. Konsep Dasar Keperawatan Kesehatan Jiwa. Jakarta. EGC.

Umar, N. 1999. Argumen Kesetaraan Gender. Jakarta. Paramadina. 